\title{
Identification of Risk Factors for Breast Cancer for Women in Istanbul
}

\author{
Sevim Çelik ${ }^{*}, 1$ and Güler Aksoy ${ }^{2}$ \\ ${ }^{I}$ Zonguldak Karaelmas University, Zonguldak School of Nursing, Surgical Nursing Department, Turkey \\ ${ }^{2}$ Istanbul University, Florence Nightingale College of Nursing, Surgical Nursing Department, Turkey
}

\begin{abstract}
Background: Breast cancer is the most common cancer type seen in women, accounts for $18 \%$ of all cancer types in women and the risk of a woman to get breast cancer during her life is $11 \%$. These notified rates enable breast cancer to be defined as a preventable and if pre-diagnosed, a treatable cancer type, despite it was regarded as a terrifying type of cancer in the past.
\end{abstract}

Objective: The aim of the study was to determine the lifestyle pattern of women without breast cancer in Istanbul.

Method: The study was carried out as a descriptive and cross-sectional study with 1000 women.

Results: The majority of the women (29.7\%) were in the 35-44 year old age group. Out of these $93.1 \%$ gave birth before the age of $30,29.5 \%$ breastfed for 7-12 months, $65.8 \%$ started menarche between 13-15 years of age (mean of 13.3 years), $15.5 \%$ were in menopause and had entered menopause at a mean age of 46.5 years. Their mean body mass index was $24.3 \mathrm{~kg} / \mathrm{m}^{2}$ and $24.5 \%$ of them preferred foods containing high fat content. The majority of the women $(85.4 \%)$ did not participate in sports regularly. One third $(30.3 \%)$ of the women had underwent Breast Self Examination. There was a positive family history of breast cancer for $12.1 \%$ of the women.

Conclusion: Sedentary lifestyles, lower Breast Self Examination and routine mammography rates and family histories of breast cancer were the risk factors that needed to be given priority for further action.

Keywords: Breast cancer, behavioral risk factors, lifestyle changes.

\section{INTRODUCTION}

Breast cancer is the most common cancer type seen in women, accounting to about $18 \%$ of all cancer types in women. Women have an $11 \%$ risk for getting breast cancer during their lifespan [1,2]. Although these reported rates would have been seen as a frightening type of cancer in the past, but today, it is seen as a preventable and, with early diagnosis, treatable type of cancer [3].

In the year 2004, it has been delineated that 371,000 new cases of breast cancer were diagnosed and it was the cause of death for 129,900 women in Europe [4]. It has been predicted that one in every 8 women will experience breast cancer during their lifetime $[5,6]$. According to data for the year 2005 in Turkey, the rate of breast cancer seen in women was $23.5 \%$, however this rate increased to $24.1 \%$. Breast cancer was primarily diagnosed in the Marmara region in 1999.

A significant proportion of determined risk factors are nonmodifiable factors, such as gender, age, race, family history, late pregnancy, early menarche and late menopause $[1,6]$. Researchers also note that modifiable factors include postmenopausal obesity from change in lifestyle, cigarette smoking and use of alcohol, physical inactivity, hormone replacement therapy, breastfeeding and reproductive lifestyle behaviors $[1,4,7-10]$. There are numerous nationally and internationally accepted studies concerning the effect of

*Address correspondence to this author at the Zonguldak Sağlık Yüksekokulu, 67100, Site/ZONGULDAK, Turkey; Tel: (90) (372) 257-4191, Ext. 119; Fax: (90) (372) 257-6750; E-mail: sevimak@superonline.com modifiable and nonmodifiable risk factors on breast cancer incidence $[3,4,7,11]$.

Turkish and Asian women reflect the model of a traditional family, in which a family aims at least two children who are breastfed by the mother. Nutritional habits of Turkish and Asian women show a preference for carbohydrates and fatty diet. Alcohol consumption is relatively restricted in these women due to cultural origin and religious obligations. But lately it has been observed that certain masses of women have started to adopt the western life style giving rise to considerable alcohol consumption and cigaratte smoking. In addition, the sedentary lifestyle of Turkish women has also contributed greatly to an increased risk of breast cancer [22].

This study was conducted for the purpose of determining lifestyle behaviors, which have important roles in preventing and controlling breast cancer in women in Istanbul.

\section{LITERATURE REVIEW}

The incidence of breast cancer is observed in women under the age of 25 , with the risk multiplying every ten years till menopause, being particularly most common at postmenopausal period after the age of 50 [12]. The risk of contracting breast cancer for a 20 years old woman in the following 10 years is $0.05 \% ; 0.44 \%$ at the age of $30 ; 1.46 \%$ at the age of $40 ; 2.73 \%$ at the age of $50 ; 3.82 \%$ at the age of 60 ; and $4.14 \%$ at the age of 70 [11].

It has been delineated that high education and socioeconomic level increase the risk of breast cancer by enhancing the neural communications within the brain thereby causing an increase in the level of estrogen. Furthermore, it has 
been highlighted that women being highly educated and maintaining a socio-economic level do have enough knowledge about the benefits of healthy nutrition, consuming which assists them in keeping good health and they start to menstruate at younger ages. Resultantly, this considerable period of time spent in getting educated, followed by exercising significant posts at work, contributes to a delay in marriage and a probable conception and childbirth at older ages, leading to an increased risk of breast cancer [13].

Early onset of menarche (before age 12) and late menopause (after age 50) are associated with increased risk of breast cancer. According to the results of case-controlled studies, the risk of breast cancer reduces per year by $20 \%$ for each year the menarche is delayed [12].

Having no children or the first full-term pregnancy by the age of 30 places a woman at an increased risk of breast cancer. When compared with the women whose age at first live birth is 18 or 19 , the risk increases 4-5 times for the women being 30 years old at first live birth with this rate being the same for the women who have not given birth. Accordingly, however, it is controversial. Researchers show that hormone replacement therapy for longer than 5 years may increase the risk by $50 \%-80 \%$ at the post-menopausal period $[4,10,14$, 15].

Studies indicate a close relationship between the duration of breast feeding and the decrease of the risk of breast cancer $[4,16]$. For women breast feeding for 12 months, the risk of breast cancer reduces by $4.3 \%$ and it also reduces by $7 \%$ for every birth [4]. Breast feeding is largely protective, as it is especially done for long time periods. When compared with women who never breast feed, it has been determined that the relative risk of breast cancer is $0.95 \%$ for those breast feeding for $7-11$ months, $0.86 \%$ for those breast feeding for $12-23$ months, $1.11 \%$ for those breast feeding for 24 months and longer. Veronesi et al. [4] analyzed the correlation between the duration of breastfeeding and risk of breast cancer. In that study they showed that there is a $4.3 \%$ reduction in the risk for women who breastfeed for 12 months with a $7 \%$ reduction at each birth.

Seven prospective cohort type reproductive studies (337.819 women and 4385 invasive breast cancer cases) have notified that there is an increase of relative risk of breast cancer related to diets and other risk factors by $1.02 \%$ for pre-menopausal women and by $1.07 \%$ for postmenopausal women [4].

There are numerous studies that are pointing to the role of regular physical activity on the possibility of decreasing the risk of breast cancer [4,6,17-19]. Friendreich et al. [20] noted that inadequate physical activity increases the risk of breast cancer by $1.43 \%-1.67 \%$. In the study conducted by Verloop et al. [21] on women aged between 20 and 54, it is expressed that physical activity in pre-menopausal women decreases the risk of breast cancer by $30 \%$. Researchers are in agreement with the issue that the density and length of physical activity are also effective in decreasing the risk of breast cancer. They emphasized that the risk of breast cancer may decrease for a quite active woman by $10-70 \%$ and the risk may lower $30-40 \%$ more for a woman doing regular exercise for 3-4 hours per week $[6,8,9,12]$.
Recent studies show that breast cancer is caused by mutations and changes in the genes BRCA I and BRCA 2, and approximately $5-10 \%$ of breast cancer cases are hereditary $[9,11]$. The International Agency for Research on Cancer predicted that the global rate of breast cancer related to obesity and sedentary lifestyle is $25 \%$ and noted that the risk increases for post-menopausal women by $50-250 \%$ [6].

Recent studies have highlighted the fact that women are becoming more aware about the causes, risk factors, and early diagnosis and treatment of breast cancer, which has also shown to be a positive inclination even in Turkey where a decline in mortality rates has been observed [11].

\section{METHODS}

\section{Study Design}

This study was conducted as a descriptive and crosssectional study.

\section{Sample}

This study was conducted in Istanbul with a total of 1000 women who were willing to participate. Data revealed the existence of approximately 3,000,000 women over 18 years of age in Istanbul and breast cancer was seen $24.1 \%$ in Turkey during the period 2005 and 2006. It was used following the calculation formula:

$$
\mathrm{n}=\frac{\mathrm{P} \cdot \mathrm{Q} \cdot \mathrm{Z}_{\alpha}^{2}}{\mathrm{~d}^{2}}
$$

Inclusion criteria in this study included women who did not have breast or any other gynecological from of cancer, were able to speak Turkish and were over 18 years of age.

Exclusion criteria for the study included women diagnosed with breast and any other gynecological from of cancer, women who were unable to speak Turkish or were health professionals. Eleven survey forms were incompletely filled out by participants therefore they were not included in the study.

\section{Major Study Variables}

Alcohol Consumption: Respondents reported their alcohol consumption status as yes or no. Quantity of alcohol consumed per month was grouped into four categories: 1-4 glasses, 5-8 glasses, 9-12 glasses and $\geq 13$ glasses.

Cigarette Smoking: Participants reported their current cigarette smoking status as yes or no. Quantity of cigarette smoking per day was grouped into five categories: 1-4 cigarettes, 5-9 cigarettes, 10-14 cigarettes, 15-19 cigarettes and $\geq 20$ cigarettes.

Nutritional Habits: The questions included the women's consumption of fresh fruits and vegetables and the consumption of fatty food.

Physical Activity: The participants reported their sports activity and walking status and duration of these activities per day.

Routine Mammography and Breast Self Examination: The questions were directed at determining health related behaviors whether the subjects had ever had a routine 
mammography and Breast Self Examination. In case they had, they reported the time of Breast Self Examination.

\section{Other Baseline Study Variables}

Researches were instructed to maintain records of the patricipants's including age, age at menarche, education level, marital status, employment status and type of occupation, pregnancy and menopausal status and the use of hormonal replacement therapy.

\section{Data Collection}

A survey form with questions about the risk factors of breast cancer was filled in by 20 women in a pilot test, followed by essential revisions in the form, as a result of which the final survey form included 50-questions.

Study data were collected in collaboration with a clinic practice by research staff. Researhers were assigned to collect information about healthy women through conducting interviews of women who visited the university hospital in Istanbul. Researchers filled out the survey form for the illiterate women after receiving their permission.

\section{Data Analysis}

Data were loaded in the Microsoft Excel software program and evaluated for number and percentages. Chi square tests were conducted to evaluate the relationships between cigarette smoking, alcohol consumption, exercise and nutritional status with age, educational status, marital status and employment status. The confidence interval of $95 \%$ was accepted.

\section{Ethical Approach}

All of the hospital directors of nursing, staff nurses and ethics board were informed about the study and their permission was received. The women were informed about the objective of the study and the contents of the survey form and were told that their identity would be kept confidential. These subjects were then asked to give their informed consent.

\section{RESULTS}

\section{Sample Characteristics}

All of the 1000 women in the study were 18 years or older, with $29.7 \%$ being in the age group of 35 and 44 years, $33.4 \%$ being university graduates, $66.2 \%$ were married and $62.6 \%$ were employed (Table 1 ).

\section{Reproductive-Related Health Behaviors}

The majority $(65.8 \%)$ of the women started menarche between 13 and 15 years of age, $62.7 \%$ had given birth, $93.1 \%$ gave birth to their first child before the age of 30

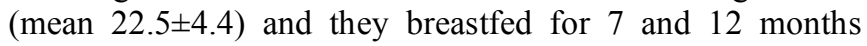
$(29.5 \%)$. It was noted that $81.5 \%$ of the women continued to menstruate, $66.5 \%$ of the women who had stopped menstruating had entered menopause under the age of 50 (mean of $46.5 \pm 5.7$ years), and $19.0 \%$ were taking hormone replacement therapy after menopause (Table 2).

\section{Health Behaviors Related to Modifiable Risk Factors}

About $87.9 \%$ of the women had never used alcohol and $73.6 \%$ of the alcohol consumers drank 1-4 glasses of alcoholic beverages per month. One third of the women $(32.9 \%)$ smoked cigarettes and about half of them used a pack or more of cigarettes per day (Table 3 ).

On examining the women's nutritional habits, it was determined that all of $61.9 \%$ women (619 individuals) ate three meals a day; $84.3 \%$ consumed fresh fruits and vegetables, $75.5 \%$ low fat products and $77.4 \%$ milk and dairy products with meals (Table 3 ).

The mean body weight of the women was $63.42 \mathrm{~kg}$ and their mean height was $161.64 \mathrm{~cm}$. These results indicated that their mean body mass index was 24.3 (within normal limits). Although only $14.6 \%$ of the women reported that they regularly participated in sports activities, $53.4 \%$ stated that they walked regularly. Those regularly participating in sports and walking were spending an average of one to two hours a day for those activities (Table 3 ).

Table 1. Demographic Characteristics of Women

\begin{tabular}{|c|c|c|}
\hline Demographic Characteristics & $\mathbf{n}$ & $\%$ \\
\hline \multicolumn{3}{|l|}{ Age $(36.6 \pm 12.1)$} \\
\hline$<25$ & 178 & 17.8 \\
\hline $25-34$ & 276 & 27.6 \\
\hline $35-44$ & 297 & 29.7 \\
\hline $45-54$ & 164 & 16.4 \\
\hline $55-64$ & 58 & 5.8 \\
\hline $65-74$ & 19 & 1.9 \\
\hline$\geq 75$ & 8 & 0.8 \\
\hline \multicolumn{3}{|l|}{ Education } \\
\hline Illiterate & 37 & 3.7 \\
\hline Literate & 37 & 3.7 \\
\hline Primary school & 253 & 25.3 \\
\hline Middle school & 89 & 8.9 \\
\hline High school & 250 & 25.0 \\
\hline University & 334 & 33.4 \\
\hline \multicolumn{3}{|l|}{$\underline{\text { Marital status }}$} \\
\hline Married & 662 & 66.2 \\
\hline Single & 262 & 26.2 \\
\hline Widowed & 64 & 6.4 \\
\hline Separated & 12 & 1.2 \\
\hline \multicolumn{3}{|l|}{ Employment status } \\
\hline Employed & 374 & 37.4 \\
\hline Unemployed & 626 & 62.6 \\
\hline \multicolumn{3}{|l|}{ Type of occupation } \\
\hline Housewife & 374 & 37.4 \\
\hline Labor-intensive work & 145 & 14.5 \\
\hline Office type work & 271 & 27.1 \\
\hline Freelance & 63 & 6.3 \\
\hline Other (student) & 147 & 14.7 \\
\hline
\end{tabular}

It was observed that women under the age of 25 , though being educated, had an inclination to consume more alcohol. In addition, alcohol consumption was also shown to be higher for employed and single women. There was a statistically, significantly higher percentage of cigarette smoking among women being highly educated and were 
employed $\left(X^{2}: 19.7 ; p=0.001\right)$. The significant differences were found in the comparison of cigarette smoking status with other variables. The rate of cigarette smoking was higher in the women between 35 and 44 years than in the other age groups.

Menopausal women had a lower exercise level than the premenopausal women and the difference was found to be statistically significant. The number of women getting regular exercise was higher at a statistically significant level in the women who were university graduates $\left(\mathrm{X}^{2}\right.$ : 17.2; $\mathrm{p}=0.004)$, employed $\left(\mathrm{X}^{2}: 5.44 ; \mathrm{p}=0.02\right)$ and married $\left(\mathrm{X}^{2}\right.$ : 23.7; $\mathrm{p}=0.000)$.

Table 2. Behaviors About Women's Reproductive Risk Factors

\begin{tabular}{|c|c|c|}
\hline Reproductive Risk Factors & $\mathbf{N}$ & $\%$ \\
\hline $\begin{array}{l}\text { Age of menarche }(13.3 \pm 1.3) \\
\quad \text { Cannot remember } \\
\quad \leq 12 \\
13-15 \\
\quad \geq 16\end{array}$ & $\begin{array}{c}41 \\
238 \\
658 \\
63\end{array}$ & $\begin{array}{c}4.1 \\
23.8 \\
65.8 \\
6.3\end{array}$ \\
\hline $\begin{array}{l}\frac{\text { Pregnancy }}{\text { Has not given birth }} \\
\text { Has given birth }\end{array}$ & $\begin{array}{l}373 \\
627\end{array}$ & $\begin{array}{l}37.3 \\
62.7\end{array}$ \\
\hline $\begin{array}{l}\text { Age at first live birth }(22.5 \pm 4.4)(\mathrm{n}=627) \\
\quad<30 \\
\geq 30\end{array}$ & $\begin{array}{c}584 \\
43\end{array}$ & $\begin{array}{c}93.1^{*} \\
6.9^{*}\end{array}$ \\
\hline $\begin{array}{l}\text { Duration of breastfeeding }(\mathrm{n}=627) \\
\text { Did not breastfeed } \\
1-3 \text { months } \\
4-6 \text { months } \\
7-12 \text { months } \\
\geq 13 \text { months }\end{array}$ & $\begin{array}{c}35 \\
106 \\
133 \\
185 \\
168\end{array}$ & $\begin{array}{c}5.6^{*} \\
16.9^{*} \\
21.2^{*} \\
29.5^{*} \\
26.8^{*}\end{array}$ \\
\hline $\begin{array}{l}\frac{\text { Menstruation }}{\text { Menstruating }} \\
\text { In menopause }\end{array}$ & $\begin{array}{l}815 \\
185\end{array}$ & $\begin{array}{l}81.5 \\
18.5\end{array}$ \\
\hline $\begin{array}{l}\text { Age of menopause } \\
\quad<50 \\
\quad 50-55 \\
\quad \geq 56\end{array}$ & $\begin{array}{c}123 \\
57 \\
5\end{array}$ & $\begin{array}{l}66.5^{*} \\
30.8^{*} \\
2.7^{*}\end{array}$ \\
\hline $\begin{array}{l}\text { Hormone replacement therapy } \\
\text { Yes } \\
\text { No }\end{array}$ & $\begin{array}{c}35 \\
150\end{array}$ & $\begin{array}{l}19.0^{*} \\
81.0^{*}\end{array}$ \\
\hline
\end{tabular}

*Percentage calculated according to number (n).

Consumption of a high fat diet was the highest in employed women and among the age interval of 25-34 years. The higher percentage of the university graduates and married women who ate high fat diets was found to be statistically significant $\left(\mathrm{X}^{2}: 40.6 ; \mathrm{p}=0.000\right)$.

\section{Health Behaviors About Early Detection}

The majority of the women in this study (79.7\%) did not undergo Breast Self Examination (BSE). Of those who did undergo BSE, 32.5\% underwent the procedure a week after the end of menstruation. The majority of the women $(97.8 \%)$ had not had a mammography test and $84.4 \%$ did not get a regular health check-up (Table 4).

The frequency of women getting screening methods decreased at a statistically significant level with increasing age, particularly in the post-menopausal period (Fig. 1).

About of $12.1 \%$ (52 women) had a member of their family presenting with breast cancer.

Table 3. Behaviors About Women's Modifiable Risk Factors

\begin{tabular}{|c|c|c|}
\hline Modifiable Risk Factors & $\mathbf{N}$ & $\%$ \\
\hline \multicolumn{3}{|l|}{ Consumption of alcohol } \\
\hline Yes & 121 & 12.1 \\
\hline No & 879 & 87.9 \\
\hline \multicolumn{3}{|l|}{ Quantity of alcohol consumed (per month), $(\mathrm{n}=121)$} \\
\hline $1-4$ glasses & 89 & $73.6^{*}$ \\
\hline $5-8$ glasses & 20 & $16.5^{*}$ \\
\hline $9-12$ glasses & 9 & $7.4^{*}$ \\
\hline$\geq 13$ glasses & 3 & $2.5^{*}$ \\
\hline \multicolumn{3}{|l|}{ Cigarette smoking } \\
\hline Yes & 329 & 32.9 \\
\hline No & 671 & 67.1 \\
\hline \multicolumn{3}{|l|}{ Quantity of smoking (per day) $(\mathrm{n}=329)$} \\
\hline 1-4 cigarettes & 52 & $15.8^{*}$ \\
\hline $5-9$ cigarettes & 53 & $16.1^{*}$ \\
\hline 10-14 cigarettes & 73 & $22.2 *$ \\
\hline 15-19 cigarettes & 11 & $3.3^{*}$ \\
\hline$\geq 20$ & 140 & $42.6^{*}$ \\
\hline \multicolumn{3}{|l|}{ Consumption of fresh fruits and vegetables } \\
\hline Yes & 843 & 84.3 \\
\hline No & 157 & 15.7 \\
\hline \multicolumn{3}{|l|}{ Consumption of fatty food } \\
\hline Yes & 245 & 24.5 \\
\hline No & 755 & 75.5 \\
\hline \multicolumn{3}{|l|}{ Regularly partipicate in sports activity } \\
\hline Yes & 146 & 14.6 \\
\hline No & 854 & 85.4 \\
\hline \multicolumn{3}{|l|}{ Duration of sports activity(per day) $(\mathrm{n}=146)$} \\
\hline $1-2$ hours & 131 & $89.7 *$ \\
\hline 3-4 hours & 14 & $9.6^{*}$ \\
\hline 5-6 hours & 1 & $0.7^{*}$ \\
\hline \multicolumn{3}{|l|}{ Walking } \\
\hline Yes & 534 & 53.4 \\
\hline No & 466 & 46.6 \\
\hline \multicolumn{3}{|l|}{ Duration of walking (per day) $(\mathrm{n}=534)$} \\
\hline $15-29$ minutes & 40 & $7.5^{*}$ \\
\hline $30-44$ minutes & 146 & $27.3 *$ \\
\hline $45-59$ minutes & 16 & $3.0^{*}$ \\
\hline$\geq 60$ minutes & 332 & $62.2 *$ \\
\hline
\end{tabular}

\section{DISCUSSION}

Many studies have associated the risk of breast cancer to factors such as cigarette smoking and the use of alcohol, 
nutritional habits, obesity, level of physical activity, menstrual and reproductive characteristics, individual's level of stress and state of depression, besides sociodemographic characteristics. It has been emphasized that these lifestyle factors may increase the risk of development of breast cancer, or, on the contrary, they may decrease the risk. In this study, based on statements given by women in Istanbul, their lifestyle related behaviors were determined, which can be used to recommend various programs and have an important role in the prevention and control of breast cancer.

Table 4. Behaviors About Early Detection of Breast Cancer of Women

\begin{tabular}{|l|c|c|}
\hline \multicolumn{1}{|c|}{ Early Detection Methods } & N & $\%$ \\
\hline \hline Breast Self Examination & 203 & 20.3 \\
Yes & 797 & 79.7 \\
No & & \\
\hline Time of Breast Self Examination $(\mathrm{n}=203)$ & 51 & $25.1^{*}$ \\
\hline Whenever it comes to mind & 66 & $32.5^{*}$ \\
A week after menstruation & 6 & $3.0^{*}$ \\
When I have pain & 45 & $22.2^{*}$ \\
With every shower & 8 & $3.9^{*}$ \\
Before and after menstruation & 5 & $2.5^{*}$ \\
Twice a month & 12 & $5.9^{*}$ \\
During menstruation & 8 & $3.9^{*}$ \\
Once a year & 1 & $0.5^{*}$ \\
First day of every month & 1 & $0.5^{*}$ \\
Every fifteenth day of each month & & \\
\hline Regular check-up & 156 & 15.6 \\
Yes & 844 & 84.4 \\
No & & \\
\hline Mammography & 22 & 2.2 \\
\hline Yes & 978 & 97.8 \\
No & & \\
\hline Cervical Pap Smear & & 39.9 \\
Yes & & 96.1 \\
\hline No & & \\
\hline Percentage calculated according to number $(\mathrm{n})$ & & \\
\hline
\end{tabular}

\section{Reproductive-Related Health Behaviors}

The incidence of breast cancer is low in women under the age of 25. It however increases every ten years until menopause and increases significantly in the postmenopausal period after the age of 50 [12].

It has been suggested that a high level of education and socioeconomic status may increase the risk of breast cancer. It has been suggested that starting to menstruate at a younger age (before the age of 12), entering menopause before the age of 50 and giving birth to their children at older ages (after the age of 30) increases the risk of breast cancer [9-

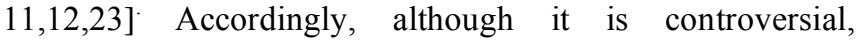
researchers have shown that hormone replacement therapy for longer than 5 years increases the risk by $50-80 \%$ in the post-menopausal period $[4,10,14,15]$.

Breastfeeding is an effective factor in the prevention of breast cancer for women who give birth; it decreases the incidence of breast cancer by $25-35 \%$ [16]. Studies have also indicated that there is a close relationship between the duration of breastfeeding and a decrease in the risk of breast cancer $[4,16]$.

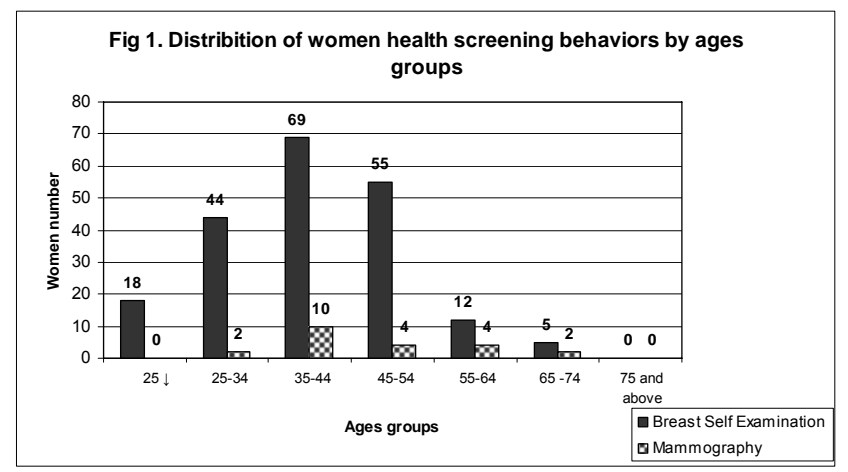

Fig. (1). Distribition of women health screening behaviors by ages groups.

In this study, the mean age of the women was 36.6 years, with $66.2 \%$ being married, $33.4 \%$ were university graduates, $62.6 \%$ were employed, and the longest place of residence for $53.8 \%$ was the city. Menarche manifested between the age of 13 and 15 for $65.8 \%$ of the women, $62.7 \%$ had given birth and $93.1 \%$ of the women who had given birth did so before their $30 \mathrm{~s}$ (mean age of 22.5 ); $29.5 \%$ breastfed their children for $7-12$ months and $26.8 \%$ for 13 months and longer, $81.5 \%$ of all women were still menstruating, $66.5 \%$ of those who were not menstruating any longer had entered menopause before their 50 s (mean age of 46.5 years) and $81 \%$ of these were not taking hormone replacement therapy after menopause. Our findings indicated that the women living in Istanbul showed behaviors supporting the results of former studies and were not at increased risk from factors related to age, menarche, menopause and age of giving first birth, or the length of breast feeding.

\section{Health Behaviors Related to Modifiable Risk Factors}

There was higher alcohol consumption among young (under the age of 25 and younger, the ages of 25-34), single, working women being highly educated and most of them were consuming 1-4 glasses of alcohol per month. Similarly, the rate of cigarette smoking was found to be higher at a statistically significant level among young and working women being highly educated (a packet or more per day). There is evidence showing that alcohol increases the risk of breast cancer, particularly if used together with cigarettes. There are many studies which report that the age when women start to drink alcohol or smoke (especially under the age of 30) and the quantity of consumption (2 glasses of alcohol per day) have a fundamental role in an increased risk of breast cancer $[6,8,11,17,24,25]$. However, most of the women in our study were not smoking or using alcohol. Risendal et al. [26] reported that women between 30-39 years old, who are single and are highly educated consume more alcohol than normal, but have a lower rate of cigarette use, however, women under 50 years who are single and employed are more active cigarette smokers. Fredman et al. [27] and Hunter and O'Dea [28] reported low rates of smoking and alcohol use.

In our study, most of the women had low-fat diets and consumed fresh fruits and vegetables. In particular, the 
women between 25-34 years who were university graduates and were married stated that they consumed high fat foods. The mean body mass index of the women in our study was within normal limits. An increase of consumption of fastfood was observed in parallel with high level of education, high socio-economic level and a fast-paced work life.

High fatty diets together with alcohol, inadequate consumption of fruits and vegetables, nutritional habits containing low roughage and rich in carbohydrates lead to obesity; consequently, they increase the risk of breast cancer by raising the level of insulin and estrogen in the bloodstream $[6,18,26,29,30]$. Obesity is regarded as an important factor, which increases the risk of breast cancer in women by $50-250 \%$, however, it is protective in the premenopausal period [4,6,31]. In the analysis of 8 cohort studies conducted with 351,825 women, it was determined that the risk of breast cancer had no relationship with the consumption of fruits and vegetables regarding their beneficial effect on decreasing the risk [6]. Malin et al. [32] also reported that nutrition mostly with fruit and vegetables could decrease the risk of breast cancer. The literature and the results of former studies suggested that the women in our study at the age of 45 and older presented eating habits, which decreased their risk of breast cancer development, however, the results are rather alarming for the younger women in our study, as they were more likely to face the risk of breast cancer in the following years due to their habits of smoking, using alcohol and eating fatty food.

The results of this study showed that $85.4 \%$ of the women living in Istanbul do not participate in sports regularly and $46.6 \%$ do not walk regularly. The women with inadequate physical activity were mostly unemployed women with a low level of education and were in their postmenopausal period. Risendal et al. [26] also reported that women who are 50 years old and over, have a low level of education and the unemployed have inadequate physical activity in parallel with the findings of our study. Although the results of the study clearly stress the role of physical activity on decreasing the risk of breast cancer, it can be seen that women in our country mostly adopt a sedentary lifestyle. There are numerous studies that point to the role of regular physical activity on the possibility of decreasing the risk of breast cancer [4,6,17-21,33].

Researchers are in agreement that intensity and duration of physical activity are also effective in decreasing the risk of breast cancer. They emphasize that the risk of breast cancer may decrease for a quite active woman by $10-70 \%$ and the risk may lower by $30-40 \%$ more for a woman who regularly exercises for 3-4 hours per week $[6,8,9,12]$.

\section{Health Behaviors About Early Detection}

One of the risk factors, which women define as the most frightening one, which has an effect on the development of breast cancer is the existence of breast cancer within the family. Recent studies indicate that $5-10 \%$ of breast cancer is hereditary and that the cancer is caused by alterations and mutations in the genes, BRCA I and II $[8,11,12]$. When the existence of any type of cancer or breast cancer in the women's family history was questioned in our study, we determined that the rate was $12.1 \%$ for breast cancer. Based on this result, the Istanbul women's positive family histories of breast cancer were characterized as a considerable risk factor. In a different study conducted by Çolak and Korkmaz [34] in Turkey, having a positive family history of breast cancer was reported to be the most serious risk factor. When we examined the women's participation in early methods of detection, it was determined that only $15.6 \%$ got a regular check-up, only $20.3 \%$ underwent regular BSE and only $2.2 \%$ would have a mammography examination. The percentages were even lower in the post-menopausal period. This result emphasize the need to increase mammography and breast self examination among the Turkish women. The literature has emphasized the use of mammography to decrease the risk of death from breast cancer by $30 \%$ for women who are over the age of $50[5,35,36]$ Madlensky et al. [29] noted that women under 40 who have not yet had a mammography screening are a more risky group for cancer. Instead of specifying the top limits, American Cancer Society recommends the age of starting BSE as 20, for breast examination as 20-39 and for mammography as 40 [37]. In the study conducted by Hunter and O'Dea [28] in which they examined how the middle-aged women perceive their risks of health in the future, it was reported that $53 \%$ of the women underwent BSE, again the percentage being much higher than the results of our study.

\section{CONCLUSION AND RECOMMENDATIONS}

The women in Istanbul have a tendency to perform healthy behaviors, which aim to decrease or prevent the risk factors presented in the results of the epidemiological study. However, the percentages of those with inadequate physical activity (particularly in non-working woman in their postmenopausal period) and the percentages of women with a family history of breast cancer were high.

The importance of the role of the multidisciplinary approach is undeniable for the prevention and early detection in women at risk for breast cancer [6] Nurses, as members of the multidisciplinary team, need to take part in every process related to breast cancer, including prevention, health education, early detection, treatment and care [11]. Nurses especially should be active about health education and awareness of public. Nurses are expected to guide women, especially in determining women who are at risk and to educate them and encourage them to receive regular screening at available health services [38].

We may conclude that nurses need to emphasize on the sedentary life style, education for BSE and mammography, and give utmost consideration to positive family history in early detection programs and in public awareness programs to prevent breast cancer.

\section{LIMITATIONS OF STUDY}

On examining the demographic data, it was observed that the study sample included women being 40 years old, therefore, it was essential that data should be generalized for such a study. Researhers should also assess housewives and not restrict the age group to 40 years and under, but those over the age of 40 should also be evaluated in the future research.

\section{REFERENCES}

[1] Aydıner A, Dinçer M, Topuz E. Meme kanseri. In: Topuz E, Aydıner A, Karadeniz AN, Eds. Klinik Onkoloji. İstanbul Üniversi- 
tesi Onkoloji Enstitüsü Yayınları, İstanbul, Tunç Matbaası, 2000; 70-81.

[2] Stasiolek D, Kwasneiewska M, Drygas W. Breast cancer: Selected risk factors, primary prevention. Przegl Lek 2002; 59: 26-30.

[3] Yılmaz M, Çetin Z, Karapınar H, Çiftçi S. Cumhuriyet üniversitesinde çalışan kadın personelin meme kanseri risk durumunun belirlenmesi. VIII. Ulusal Meme Hastalıkları Kongresi, 21-24 Eylül, Lütfi Kırdar Kongre ve Sergi Sarayı, İstanbul. 2005.

[4] Veronesi U, Boyle P, Goldhirsch A, Orecchia, Viale G. Breast Cancer. Lancet 2005; 365: 1727-41.

[5] Wright T, McGechan A. Breast cancer: new technologies for risk assessment and diagnosis. Mol Diagn 2003; 7: 49-55.

[6] McTeirnan A. Behavioral risk factors in breast cancer: can risk be modified? Oncologist 2003; 8: 326-34.

[7] Emmons KM, Kalkbrenner KJ, Klar N, Light T, Katherine AS, Garber JE. Behavioral risk factors among women presenting for genetic testing. Cancer Epidemiol Biaomarkers Prev 2000; 9: 8994.

[8] Korde LA, Calzone KA, Zujewski J. Assessing breast cancer risk: genetic factors are not the whole story. Postgrad Med 2004; 116: 68, 11-4, 19-20.

[9] Mertens AJ, Sweeney C, Sharar E, Rosamond WD, Folsom AR. Physical activity and breast cancer incidence in middle-aged women: a prospective cohort study. Breast Cancer Res Treat 2006; 97: 209-14.

[10] Okobia MN, Bunker CH. Epidemiological risk factors for breast cancer-a review. Niger J Clin Pract 2005; 8: 35-42.

[11] Sevil Ü, Ünsal Ş. Meme kanserinde risk faktörleri ve erken tanı. Hemşirelik Forumu Dergisi 2002; 5: 32-39.

[12] Lewis MS, Heitkemper MM, Dirksen SR, Eds. Medical Surgical Nursing, St Louis: Mosby; 2004.

[13] Hilakivi-Clarke L. Estrogen-regulated non-reproductive behaviors and breast cancer risk: animal models and human studies. Breast Cancer Res Treat 1997; 46: 143-159.

[14] Chen CL, Weiss NS, Newcomb P, Barlow W, White E. Hormone replacement therapy in relation to breast cancer. JAMA 2002; 287: $734-41$.

[15] Pritchart KI. Hormone replacement in women with a history of breast cancer. Oncologist 2001; 6: 353-362.

[16] Lipworth L, Bailey LR, Trichopoulus D. History of breast-feeding in relation to breast cancer risk: a review of the epidemiologic literature. J Natl Cancer Inst 2000; 92: 302-12.

[17] Key TJ, Schatzkin A, Willett WC, Allen NE, Spencer EA, Travis RC. Diet, nutrition and the prevention of cancer. Public Health Nutr 2004; 7: 187-200.

[18] Garrett NA, Brasure M, Schmitz KH, Schultz MM, Huber MR. Physical inactivity direct cost to a health plan. Am J Prev Med 2004; 27: 304-309.

[19] Rabin CS, Pinto BM, Trunzo JJ, Frierson GM, Bucknam LM. Physical activity among breast cancer survivors: regular exercisers vs participants in a physical activity intervention. Psychooncology 2006; 15 : 344-54.

[20] Friendreich CM. Physical activity and cancer prevention: from observational to intervention research. Cancer Epidemiol Biomarkers Prev 2001; 10: 287-301.
[21] Verloop J, Rookus MA, Kooy K, Leeuwen FE. Physical activity and breast cancer risk in women aged 20-54 years. J Natl Cancer Inst 2000; 92: 128-35.

[22] Aslan FE, Gürkan A. Kadınlarda meme kanseri risk düzeyi. Meme Sağ lı̆̆ı Dergisi 2007; 3: 63-68.

[23] Butler LM, Potischman NA, Newman B, et al. Menstrual risk factors and early-onset breast cancer. Cancer Causes Control 2000; 11: 451-58.

[24] Morabia A. Smoking (active and passive) and breast cancer: epidemiologic evidence up to Juna 2001. Environ Mol Mutagen 2002; 39: 89-95.

[25] Rohan TE, Jain M, Howe GR, Miller AB. Alcohol consumption and risk of breast cancer: a cohort study. Cancer Causes Control 2000; 11: 239-47.

[26] Risendal B, Dezapien J, Fowler B, Papenfuss M, Giuliano A. Cancer prevention among urban southwestern american indian women: comparison to selected year 2000 national health objectives. Ann Epidemiol 1999; 9: 383-390.

[27] Fredman L, Sexton M, Cui Y, et al. Cigarette smoking, alcohol consumption, and mammography among women ages 50 and older. Prev Med 1999; 28: 407-417.

[28] Hunter MS, O'Dea I. Perception of future health risks in mid-aged women: estimates with and without behavioral changes and hormone replacement therapy. Maturitas 1999; 33: 37-43.

[29] Madlensky L, Vierkant RA, Vachon CM, et al. Preventive health behaviors and familial breast cancer. Cancer Epidemiol Biomarkers Prev 2005; 14: 2340-5.

[30] Stoll BA. Upper abdominal obesity, insulin resistance and breast cancer risk. I J Obes Relat Metab Disord 2002; 26: 747-53.

[31] Thompson HJ, Zhu Z, Jiang W. Weigh control and breast cancer prevention: are the effects of reduced energy intake equivalent to those of increased energy expenditure?. J Nutr 2004; 134: 3407S3411S.

[32] Malin AS, Qi D, Shu XO, et al. Intake of fruits, vegetables and selected micronutrients in relation to the risk of breast cancer. Int $\mathrm{J}$ Cancer 2003; 105: 413-8.

[33] Shoff SM, Newcomb PA, Trentham-Dietz A, et al. Early-life physical activity and postmenopausal breast cancer: effect of body size and weight change. Cancer Epidemiol Biomarkers Prev 2000; 9: 591-595.

[34] Colak T, Korkmaz B. Meme kanseri risk faktörleri vaka-kontrol çalışması. VIII. Ulusal Meme Hastalıkları Kongresi, 21-24 Eylül, Lütfi Kırdar Kongre ve Sergi Sarayı, İstanbul, 2005.

[35] Hall HI, Uhler R, Coughlin SS, Miller DS. Breast and cervical cancer screening among Appachian women. Cancer Epidemiol Biomarkers Prev 2002; 11: 137-142.

[36] Rakowski W, Bren N, Meissner H, et al. Prevalence and correlates of repeat mammography among women aged 55-79 in the Year 2000. Natl Health Interv Survey 2004; 39: 1-10.

[37] Smith RA, Cokkinides V, Eyre HJ. American Cancer Society Guidelines fort he early detection cancer, 2003. CA Cancer J Clin 2003; 53: 27-43.

[38] Conto SI, Myers JS. Risk factors and health promotion in families of patient with breast cancer. Clin J Oncol Nurs 2002; 6: 83-87. 